Article - Agriculture, Agribusiness and Biotechnology

\title{
A Rapid and Reliable Method for Molecular Detection of Fusarium guttiforme, the Etiological Agent of Pineapple Fusariosis
}

\author{
Lorena Carnielli-Queiroz ${ }^{1^{*}}$ \\ https://orcid.org/0000-0002-3834-8358 \\ Patricia Machado Bueno Fernandes ${ }^{1}$ \\ https://orcid.org/0000-0003-2695-3638
}

Antônio Alberto Ribeiro Fernandes ${ }^{1}$

https://orcid.org/0000-0002-8261-9717

José Aires Ventura ${ }^{1,2}$

https://orcid.org/0000-0003-1422-1739

${ }^{1}$ Federal University of Espírito Santo, Biotechnology Center, Vitória, ES, Brazil; ${ }^{2}$ Institute of Research, Technical Assistance and Rural Extension of Espírito Santo- Incaper, Vitória, ES, Brazil.

Received: 2018.10.22; Accepted: 2019.07.21.

*Correspondence: Icarnielliqueiroz@gmail.com; Tel.: +55-27-33241189 (L.C.Q., P.M.B.F., A.A.R.F.; J.A.V.).

\section{HIGHLIGHTS}

- A rapid and reliable diagnosis of Fusarium guttiforme in pure cultures and infected pineapple;

- F. guttiforme could be easily distinguished from other Fusarium species by real-time PCR;

- A molecular method provide support and can be helpful for effective disease management;

- New method for indexation of pineapple propagative material for phytosanitary defence.

Abstract: Pineapple (Ananas comosus var. comosus) fusariosis is an economically important fungal disease affecting the plant and its fruit. A rapid and reliable diagnosis is the base of integrated disease management practices. Fusariosis has resulted in quarantines for pineapple products in Central America, Africa and Asia. Difficulties diagnosing and correctly identifying the fungus Fusarium guttiforme, agent of the pineapple fusariosis, have led to the search for new methodologies, and for this we developed a new reliable molecular method to detect it. For diagnostic purposes, real-time PCR of elongation factor gene 1- $\alpha$ (ef1) was used to rapidly, specifically and sensitively diagnose $F$. guttiforme. A pathogenicity 
test was conducted with slips of the pineapple cultivar Pérola, a multiplex PCR was run, and the results compared with those obtained with real-time PCR. The real-time PCR assay with its specific primer set could readity distinguish $F$. guttiforme from other Fusarium species known to occur on pineapple. The real-time PCR test had 95\% sensitivity and 100\% specificity with a significance level $p<0.0001$. For field samples the test had $100 \%$ sensitivity and specificity. Thus, this new test is fit for use in serial analyses of pineapples, and may have application in the evaluation of propagation materials and making quarantine decisions. The ability to rapidly and specifically detect $F$. guttiforme in plant samples will facilitate monitoring of the pathogen and improve disease management.

Keywords: Diagnostic; Diseases; Quarantine; Real-time PCR.

\section{INTRODUCTION}

Pineapple is the fruit of Ananas comosus var. comosus plant that originated in the tropical region of the Americas wherefrom it was spread around the world [1,2]. It is one of the most-produced fruits in the world, particularly in Costa Rica, Brazil, Philippines, India and Thailand [3].

This crop has serious phytosanitary problems, which cause economic losses and limit export of pineapples [4,5]. The fusariosis caused by Fusarium guttiforme is considered the most serious fungal disease of pineapple, with losses estimated at 30 to $40 \%$ of the fruit and up to $20 \%$ of the vegetative propagative material [6]. Fusariosis also is a major limiting factor for pineapple production in Brazil because of phytosanitary quarantines by countries in Central America, Africa and Asia where pineapple cultivation is economically important [7]. These countries currently are free of $F$. guttiforme and require compliance with phytosanitary rules and procedures that can be notified with rapid diagnostics to facilitate quarantine logistics, avoid the introduction of the pathogen and curtail potential economic losses [8]

Historically, identification of $F$. guttiforme is based on morphological characteristics and pathogenicity tests with susceptible pineapple varieties. Fusarium identification by microscopy requires highly trained staff and is limited by time to culture and observe the fungus. Furthermore, the fungus is difficult to detect in plant tissues, and these tissues may contain other Fusarium species [6,9,10]. F. guttiforme is part of the Fusarium fujikuroi species complex (FFSC), which has a controversial taxonomy based on the traditional classification scheme for the genus [11]. The development of new techniques to identify this fungus in a more rapid, highly specific and sensitive manner is extremely important $[10,12]$. Molecular diagnostics currently are the most suitable methods to complement the morphological identification, and can overcome sample contamination with other and the need to resolve sometimes inconsistent morphological markers.

Real-time PCR is a molecular diagnostic tool that has high sensitivity, and specificity, allowing direct identification of the pathogen, with low risk of false negatives, based on only a small amount of DNA [13]. Many studies have used PCR and other molecular diagnostic tools to identify plant pathogens in complex mixtures even when fungal mycelia are invisible microscopically. Real-time PCR tests have been widely used to detect disease-causing agents in humans, also are being increasingly used as rapid diagnostic tests for plant diseases [14] Rapid and accurate detection and quantification of $F$. guttiforme would be of great value for diagnosing and monitoring pineapple fusariosis. 
The aim of the study was to develop a sensitive and specific real-time PCR assay for detecting and quantifying $F$. guttiforme, using in vitro pure cultures and infected tissues from pineapple plants.

\section{MATERIAL AND METHODS}

\section{Fungi Isolates}

F. guttiforme isolates from pineapple were used in this study. Samples belong to the mycology collection of the Phytopathology Laboratory of the Instituto Capixaba de Pesquisa, Assistência Técnica e Extensão Rural - Incaper. As reference strains $F$. guttiforme (Agricultural Research Service Culture Collection - NRRL 25624), Fusarium ananatum (Centraalbureau voor Schimmelcultures - CBS 118516, CBS 118517, CBS 118518 and CBS 118519) and Fusarium spp. (Incaper Mycological Collection - E-623 and E-626) were selected.

\section{Morphological Features}

Pure cultures obtained from a single spore of each isolate were grown on Potato Dextrose Agar (PDA) to study colony morphology and pigmentation. The morphological identification of the isolates was carried out by plating then on synthetic low nutrient medium Spezieller Nährstoffarmer Agar (SNA) and sterile Carnation Leaf Agar (CLA) [9]. Cultures were incubated at $25^{\circ} \mathrm{C}$, under intermittent light (12h under fluorescent light) and dark period (12h dark photoperiod). All isolates were examined after 10-14 days using light microscopy, and the size, shape and septation of the conidia produced on the aerial mycelium, were evaluated and phialides and sporodochia were measured. Identification followed the taxonomic keys and guides available for Fusarium $[9,15]$.

\section{Pathogenicity}

Thirty isolates, including reference strains, were used for pathogenicity testing on the susceptible pineapple cultivar (cv.) Pérola. Inoculations were performed with a completely randomised design with two replications in pineapple slips with a circular lesion $4 \mathrm{~mm}$ in diameter and approximately $2 \mathrm{~mm}$ deep, in which the fungal disc was deposited, before cultivation on PDA. The inoculated slips were incubated in a moist chamber at $25^{\circ} \mathrm{C}\left( \pm 2{ }^{\circ} \mathrm{C}\right)$ under laboratory light conditions. Isolate NRRL 25624 of $F$. guttiforme was used as the reference for pathogenicity. As a control, slips were inoculated with only autoclaved PDA. To confirm the virulence of the isolates, the slips were evaluated after 30 days to determine the presence of disease signs and symptoms and the length of the lesions from the inoculation points.

\section{DNA Extraction}

\section{Isolates}

Thirty isolates, including reference strains, were cultivated on PDA at $25^{\circ} \mathrm{C}\left( \pm 2^{\circ} \mathrm{C}\right)$ for 7 days. The mycelium was used for the DNA extraction that was performed with DNeasy® Plant Mini Kit (QIAGEN $\left.{ }^{\circledR}\right)$. 


\section{Pineapples Tissues}

Pineapple slips (cv. Pérola) were inoculated with 30 Fusarium strains and incubated at $25^{\circ} \mathrm{C}\left( \pm 2{ }^{\circ} \mathrm{C}\right)$ under laboratory light conditions. After 30 days, the DNA extraction was conducted using the Raeder \& Broda protocol [16], adapted by the Laboratory of Biotechnology Applied to Agribusiness of the Federal University of Espírito Santo (Universidade Federal do Espírito Santo - Ufes). The tissues of the pineapple slips were removed and transferred to $1.5 \mathrm{~mL}$ microtubes with liquid nitrogen. After stirring and addition of $0.5 \%$ SDS buffer, the samples were kept in a water bath at $65^{\circ} \mathrm{C}$ for $20 \mathrm{~min}$. A total of 470 $\mu \mathrm{L}$ phenol and $230 \mu \mathrm{L}$ chloroform were added to the homogenised and centrifuged mixture. The aqueous phase was recovered and $300 \mu \mathrm{L}$ chloroform was added to it. After another centrifugation step, the aqueous phase was recovered and the equivalent of $60 \%$ of isopropanol was added. The supernatant was discarded and the precipitate was washed in $500 \mu \mathrm{L} \mathrm{70 \%} \mathrm{ethanol.} \mathrm{After} \mathrm{drying,} \mathrm{the} \mathrm{DNA} \mathrm{precipitate} \mathrm{was} \mathrm{resuspended} \mathrm{with} \mathrm{Tris-EDTA} \mathrm{1X}$ buffer and RNase A buffer and then, was incubated in a water bath at $65^{\circ} \mathrm{C}$ for $30 \mathrm{~min}$.

In addition, 7 pineapples slips and 2 pineapples fruits from the Incaper Experimental Farm in Sooretama, Espírito Santo, Brazil, was used to perform the experiments. All samples were visually analysed for disease symptoms and classified as either symptomatic or asymptomatic and then submitted to the extraction protocol described above. A healthy plant was used as negative control.

\section{Multiplex PCR}

Multiplex PCR was performed for Fusarium isolates. The elongation factor gene 1- $\alpha$ (ef1)[17] and $\beta$-tubulin (tub2)[18] were the selected genes. For amplification of the fragment of ef1 (640bp), Ef-1 (forward; 5'-ATGGGTAAGGAGGACAAGAC-3') and Ef-2 (reverse; 5'-GGAAGTACCAGTGATCATGTT-3') primers were used [17]. For tub2 (540bp), T1 (forward; 5'-AACATGCGTGAGATTGTAAGT-3') and T2 (reverse; 5'-TAGTGACCCTTGGCCCAGTTG-3') [18] primers were used. PCR was conducted on a Veriti® thermocycler (Applied Biosystems). The full reaction volume was $20 \mu \mathrm{l}$, containing $2.0 \mu \mathrm{l}$ Taq buffer with $0.6 \mu \mathrm{MgCl}_{2}(2,5 \mathrm{mM}), 2.0 \mu \mathrm{l}$ dNTPs $(250 \mathrm{mM}), 0.1 \mu \mathrm{l}$ of each primer $(10 \mu \mathrm{M}), 2.0 \mu \mathrm{l}$ of DNA (40 ng) and $0.2 \mu \mathrm{l}$ Taq polymerase (0.5U) (LGC Biotecnologia). The cycle conditions were: (1) denaturation at $94^{\circ} \mathrm{C}$ for $3 \mathrm{~min}$; (2) followed by 35 cycles of denaturation at $94^{\circ} \mathrm{C}$ for $45 \mathrm{~s}$; (3) annealing at $57^{\circ} \mathrm{C}$ for $30 \mathrm{~s}$; (4) extension at $72^{\circ} \mathrm{C}$ for 1.5 $\mathrm{min}$; and (6) final extension at $72^{\circ} \mathrm{C}$ for $10 \mathrm{~min}$. The PCR products were separated by electrophoresis on a 1.5\% agarose gel containing ethidium bromide. The fragments were visualised under ultraviolet light.

\section{Real-Time PCR}

A real-time PCR assay was developed for pineapple slips and fruits. Primers were designed for ef1 (ef-1aF: 5'GGTATCGACAAGCGAACCAT3' and ef-1bR: 5'CACGTTTCGAGTCGTATGGA3') and for tub2 (bTaF: 5'GATGGCTGCTTCAGACTTCC3' and bTbR: 5'TCCTCGACCTCCTTCATAGC3') with the Primer3Plus tool [19]. Fast 7500'м Real-Time PCR equipment (ABI 6.200, Applied Biosystems, California, USA) was used. The 
full reaction volume was $12.5 \mu$ l, containing 1.0 $\mu$ I DNA, $7.5 \mu$ SYBR Green PCR Master Mix kit (Applied Biosystems, California, USA) and $1.0 \mu \mathrm{l}$ of each primer at a concentration of 10 $\mu \mathrm{M}$. The samples were subjected to an initial cycle of $50^{\circ} \mathrm{C}$ for $2 \mathrm{~min}$, followed by a cycle of $95^{\circ} \mathrm{C}$ for $10 \mathrm{~min}, 40$ cycles of $95^{\circ} \mathrm{C}$ for $15 \mathrm{~s}$ and $60^{\circ} \mathrm{C}$ for $1 \mathrm{~min}$, ending with a cycle of $95^{\circ} \mathrm{C}$ for $15 \mathrm{~s}$. A negative control reaction was included in all runs.

The fluorescence threshold was adjusted for each experiment. A standard curve was generated by using known concentrations of fungal DNA (60 $\mu \mathrm{g}-1.875 \mu \mathrm{g})$. Cycle threshold values $(C t)<35$ were considered positive.

\section{Statistical Analysis}

A descriptive statistical treatment was used to analyse the data (mean and standard deviation). To evaluate the performance of our methods against the standard diagnostic technique, a chi-squared $\left(X^{2}\right)$ contingency test was conducted to determine if the sensitivity and specificity differed with a significance of $\alpha<0.05$.

\section{RESULTS}

All micromorphological traits present in the isolates were consistent with those described by Nirenberg and O'Donnell [15] and Leslie and Summerell [9] for F. guttiforme.

\section{Pathogenicity and Virulence Evaluation}

The size of the lesions ranged from limited to the inoculation point up to necrotic lesions of over $15 \mathrm{~mm}$ long. The control and reference isolates, CBS 118516, CBS 118517, CBS 118518, CBS 118519, E-623 and E-626, remained asymptomatic.

Of the 24 isolates analysed, $4(17 \%)$ did not develop fusariosis symptoms and $8(33 \%)$ had high severity lesions $>15 \mathrm{~mm}$ in length. The other 12 pathogenic samples $(50 \%)$ had lesions that varied in severity from lesions restricted to the inoculation point $(\leq 15 \mathrm{~mm})$.

\section{Identification of Isolates by Multiplex PCR}

Of the isolates analysed, 15 were positive and 9 were negative, as well as the controls strains (CBS 118516, CBS 118517, CBS 118518, CBS 118519, E-623 and E-626). The amplified fragments were $\sim 540$ bp for the tub2 gene and $\sim 640$ bp for the ef1 gene. In comparison with the pathogenicity test, the multiplex PCR obtained a sensitivity of $74 \%$ and a specificity of $91 \%$.

\section{Fusariosis Diagnosis by Real-Time PCR Protocol}

\section{Relative Amplification Efficiency}

To optimise the efficiency of the primer pairs for the ef1 and tub2 genes, a serial dilution of DNA was performed at a ratio of $1: 2$ from a concentration of $60 \mathrm{ng} / \mu \mathrm{L}$. The amplification efficiency of the primers is shown in Table 1.

Table 1 Relative amplification efficiency for real-time PCR of the ef1 (primers ef1a/ef1b) and tub2 (primers bTa/bTb) genes.

\begin{tabular}{cccc}
\hline Primers & Slope & Relative Efficiency (\%) & $\mathbf{R}^{2}$ \\
\hline
\end{tabular}




\begin{tabular}{cccc}
\hline ef1a/ef1b & -3.38 & 97.4 & 0.999 \\
bTa/bTb & -3.29 & 101.1 & 0.965 \\
\hline
\end{tabular}

Primer Specificity

F. ananatum isolates were chosen as negative controls for the species, as they have been identified by Jacobs et al. [20] as the cause of early blight in pineapple. In the study, the fluorescence threshold was 0.268 . The specificity results were favourable for the ef 1 gene primer, which did not result in any amplification in the $F$. ananatum sample (Table 2). However, the tub2 gene was amplified DNA from the $F$. ananatum isolates and was insufficient for diagnosis.

Table 2 Primer specificity as assessed by cycle threshold $(C t)$ values for ef1 (primers ef1a/ef1b) and tub2 (primers bTa/bTb) genes.

\begin{tabular}{ccc}
\hline \multirow{2}{*}{ Sample } & \multicolumn{2}{c}{ Ct values } \\
\cline { 2 - 3 } & ef1a/ef1b & bTa/bTb \\
\hline Negative Control & Undetermined & Undetermined \\
Asymptomatic & Undetermined & Undetermined \\
Symptomatic & 22.70 & 22.18 \\
F.guttiforme (NRRL 25624) & 22.31 & 21.17 \\
F.ananatum (CBS 118518) & Undetermined & 30.36 \\
\hline
\end{tabular}

Detection of F. guttiforme in Plant by Real-Time PCR

As an initial experiment, we performed the real-time PCR of the 24 samples to obtain results that could be compared with the multiplex PCR methodology. Of these 24 analysed samples, 4 were asymptomatic and 20 had lesion patterns and sizes typical of the disease.

The results for the 4 asymptomatic samples ( $C t=$ undetermined $)$ confirmed the absence of the disease. Of the 20 symptomatic samples, 19 were positive $(C t<35)$, but one presented an undetermined $C t$ that led to a false negative diagnosis of infection, most likely because the sample contained other pathogens. All of the negative controls had their results confirmed. Hence, the test had excellent sensitivity $(95.0 \%)$, specificity $(100 \%)$ and accuracy (97\%) with a significance level $p<0.0001$.

A second experiment was performed with 9 field samples. A visual classification was performed to determine their status as either symptomatic or asymptomatic plants for fusariosis. Seven had the typical disease pattern and two were asymptomatic. These results were completely consistent with those obtained in the detection by real-time PCR with 100\% sensitivity and specificity (Table 3).

Table 3 Molecular detection of $F$. guttiforme and cycle threshold $(C t)$ values for the field samples for ef1 gene (ef1a/ef1b).

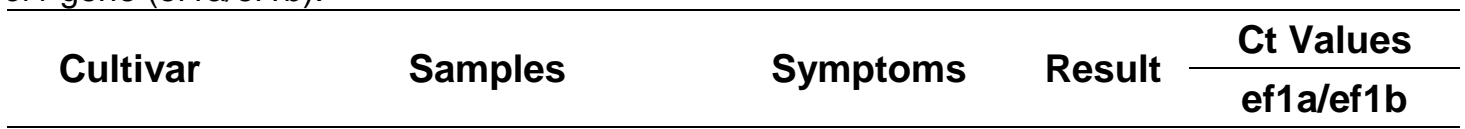




\begin{tabular}{|c|c|c|c|c|}
\hline S. Cayenne & Seedling (01) & Symptomatic & + & 29.82 \\
\hline Pérola & Seedling (02) & Symptomatic & + & 28.87 \\
\hline Pérola & Seedling (03) & Asymptomatic & - & $\begin{array}{c}\text { Undetermine } \\
\text { d }\end{array}$ \\
\hline Pérola & Seedling (04) & Symptomatic & + & 28.55 \\
\hline Pérola & Seedling (05) & Asymptomatic & - & $\begin{array}{l}\text { Undetermine } \\
\text { d }\end{array}$ \\
\hline Pérola & Seedling (07) & Symptomatic & + & 32.69 \\
\hline Pérola & Seedling (08) & Symptomatic & + & 23.98 \\
\hline Pérola & Fruit (10) & Symptomatic & + & 29.40 \\
\hline S. Cayenne & Fruit (11) & Symptomatic & + & 28.47 \\
\hline- & $\begin{array}{c}\text { F.guttiforme (NRRL } \\
25624)\end{array}$ & - & + & 22.81 \\
\hline- & Negative Control ${ }^{1}$ & $=$ & - & $\begin{array}{c}\text { Undetermine } \\
\text { d }\end{array}$ \\
\hline- & $\begin{array}{c}\text { F.ananatum (CBS } \\
118518)\end{array}$ & $=$ & - & $\begin{array}{c}\text { Undetermine } \\
\text { d }\end{array}$ \\
\hline- & Healthy Plant & $=$ & - & $\begin{array}{c}\text { Undetermine } \\
\text { d }\end{array}$ \\
\hline
\end{tabular}

${ }^{1}$ Negative control $=$ represents the experiment control, i.e., test with DNA absence.

\section{DISCUSSION}

The pineapple fusariosis caused by $F$. guttiforme is considered the most damaging disease in Brazil and other South American countries [21]. Pathogenicity and virulence studies are important to understand and generate control measures in phytopathological diseases but, no references were found to demonstrate the different degrees of lesions caused by $F$. guttiforme strains. Somehow, an interesting reference demonstrated the reduction in leaf scale numbers was related to lower infection levels and that it could be a start for control strategies [22].

Considering the importance of species identification, particularly the quarantine pathogens, which has a significant economic impact [23], this study developed a method for the detection of F. guttiforme. tub2 and ef1 genes were chosen because they are widely used in the phylogeny and identification of Fusarium species [24]. The first test was performed with Multiplex PCR in order to reduce the identification time, cost and the number of false negatives due to more targets for the same species in the same reaction. However, the specificity and efficiency compared to the pathogenicity results were not satisfactory.

In order to obtaining greater accuracy, we used real-time PCR. Although the choice of tub2 and tef1 genes, the tub2 gene carried out in a real-time PCR were not specific, amplifying the $F$. ananatum isolates. A growing number of annotated sequences have been deposited in databases, often without strict control or any prior confirmation, which can lead to incorrect identification of organisms and improper use of sequences for the generation of primers. Importantly, the inadequate use of specific primers to amplify certain species, can 
lead to diagnostic errors, resulting in incorrect identifications and lots of other problems. Therefore, prior specificity diagnosis of primers is indispensable, as shown in this study.

Phylogenetic studies with fungi of the genus Fusarium $[11,25]$ have shown that the ef1 has sufficient variability among species, making it possible to design specific tests that allow biomass detection and quantification for a broad spectrum of Fusarium species [26]. Thus, it is appropriate to use a real-time PCR assay to identify $F$. guttiforme using the ef1 gene.

Conventional PCR analysis takes $\sim 6 \mathrm{~h}$ to perform from the preparation of samples to visualisation on the agarose gel, whereas real-time PCR can be completed within $2.5 \mathrm{~h}$ [27]. As demonstrated in this study, it is also possible to find significant differences between the results obtained by conventional PCR and those obtained by real-time PCR [28]. In different areas the results have demonstrated that real-time PCR method is more specific and effective. To check the progress of real-time PCR for visceral leishmaniasis diagnosis, researchers compared different PCR methods in the bone marrow of dogs and found 54 and $84 \%$ of positive results respectively for PCR and real-time PCR [29]. Others researchers compared three different PCR protocols for the detection of fungal DNA from clinical samples and showed real-time PCR to be the most sensitive method [30].

For plant pathogens, detection and identification still often relies on methods that are based upon morphological characterization and molecular methods are not routinely used $[31,32]$. An example is the use of the real-time PCR to quantify fungus species in a food sample where small difference in reaction efficiency can result in a difference in the final product quantity [33]. Other example is the detection of the fungus that causes disease in pine. Researches assess the efficiency of different PCR techniques on a set of naturally infected samples. The results demonstrated better efficacy of real-time PCR for detection of the analyzed pathogens [34].

The simplicity, specificity and high sensitivity with respect to the probe and dye reduces the risk of post-amplification contamination, while allowing high production potential, continuous introduction of new chemicals, detection of relatively small amounts of target DNA, ease of quantification and improvement in protocols [27]. Lievens et al. [35] conducted a real-time PCR study to detect and quantify pathogens that cause disease in tomato plants. By isolating samples from the plants and their soil, they obtained accurate quantification of the target, even from soil samples that naturally contain a large variety of microorganisms.

Identification of the causal pathogen of fusariosis disease was necessary due to the complex nature of the pathogen(s) associated with the pineapple. It appears that our real-time PCR diagnosis protocol was applicable to screen naturally $F$. guttiforme infected pineapple samples. The high cost of equipment and reagents required for molecular biology increases the difficulty of using protocols such as this for routine diagnostics. However, real-time PCR with SYBR Green can reduce these costs considerably, along with the time required to conduct the procedure. Thus, for diagnosis of pineapple fusariosis caused by $F$. guttiforme, real-time PCR represent a low-cost, high sensitivity and high specificity method compared to other molecular diagnostic procedures and even standard pathogen isolation techniques from infected plant tissues.

\section{CONCLUSION}


Real-time PCR is a consolidated technique and has great potential for applications in phytopathological diagnostics. The proposed method was highly specific and sensitive for the diagnosis of $F$. guttiforme in pineapple tissues, as well as identification of the fungus in pure cultures. The sensitivity and rapidity of the technique described here support its application in the study of the etiology and epidemiology of pineapple fusariosis.

Funding: This research received no external funding

Acknowledgments: This research was supported in part by Conselho Nacional de Desenvolvimento Tecnológico e Científico (CNPq) and Fundação de Amparo a Pesquisa do Espírito Santo (FAPES).

Conflicts of Interest: "The authors declare no conflict of interest."

\section{REFERENCES}

1. Ma, C; Xiao, SY; Li, ZG; Wang, W; Du, LJ. Characterization of Active Phenolic Components in the Ethanolic Extract of Ananas Comosus L. Leaves Using High-Performance Liquid Chromatography with Diode Array Detection and Tandem Mass Spectrometry. J. Chromatogr.

A. 2007;1165:39-44.

2. Ogawa EM, Costa HB, Ventura JA, Caetano LCS, Pinto FE, Oliveira BG, Barroso MES, Scherer R, Endringer DC, Romão W. Chemical Profile of Pineapple Cv. Vitória in Different Maturation Stages Using Electrospray Ionization Mass Spectrometry. J. Sci. Food Agric. 2018;98(3):1105-16.

3. Food and Agriculture Organization of the United Nations Available online: http://faostat.fao.org/beta/en/\#data/QC/visualize (accessed on 5 Feb 2018).

4. Santos B, Zambolim L, Ventura J, Vale F. Severidade de Isolados de Fusarium Subglutinans $f$. Sp. Ananas Sensíveis e Resistentes Ao Benomyl, Em Abacaxizeiro. Fitopatol. Bras. 2002;27:101-3.

5. Stepień $Ł$, Koczyk G, Waśkiewicz A. Diversity of Fusarium Species and Mycotoxins Contaminating Pineapple. J. Appl. Genet. 2013;54(3):367-80.

6. Ventura JÁ, Costa H, Cabralc JRS, De Matosd AP. Vitória: New Pineapple Cultivar Resistant to Fusariosis. Acta Hortic. 2009;822:51-6.

7. JA V, Zambolim L. Controle Das Doenças Do Abacaxizeiro. In Controle de doenças de plantas: fruteiras; UFV: Viçosa. 2002;pp. 445-510.

8. Schaad NW, Frederick RD, Shaw J, Schneider WL, Hickson R, Petrillo MD, Luster DG. Advances in Molecular-Based Diagnostics in Meeting Crop Biosecurity and Phytosanitary Issues. Annu Rev Phytopathol. 2003;41:305-24.

9. Leslie JF, Summerell BA. The Fusarium Laboratory Manual; 1st ed.; Blackwell Publishing: lowa, USA, 2006.

10. Santos C, Ventura JA, Costa H, Fernandes PMB, Lima N. MALDI-TOF MS to Identify the Pineapple Pathogen Fusarium Guttiforme and Its Antagonist Trichoderma Asperellum on Decayed Pineapple. Trop. Plant Pathol. 2015;40:227-32.

11. O'Donnell K, Cigelnik E, Nirenberg HI. Molecular Systematics and Phylogeography of the Gibberella Fujikuroi Species Complex. Mycologia. 1998;90:433-58.

12. Dean TR, Roop B, Betancourt D, Menetrez MY. A Simple Multiplex Polymerase Chain Reaction Assay for the Identification of Four Environmentally Relevant Fungal Contaminants. J. Microbiol. Methods. 2005;61:9-16.

13. Yao CL, Magill CW, Frederiksen RA, Bonde MR, Wang Y, Wu PS. Detection and Identification of 
Peronosclerospora-Sacchari in Maize by DNA Hybridization. Phytopathology. 1991;81:901-5.

14. Deepak SA, Kottapalli KR, Rakwal R, Oros G, Rangappa KS, Iwahashi H, Masuo Y, Agrawal GK. Real-Time PCR: Revolutionizing Detection and Expression Analysis of Genes. Curr. Genomics. 2007;8(4):234-51.

15. Nirenberg HI, O'Donnell K. New Fusarium Species and Combinations within the Gibberella Fujikuroi Species Complex. Mycologia. 1998;90:434-58.

16. Raeder U, Broda P. Rapid Preparation of DNA from Filamentous Fungi. Lett. Appl. Microbiol. 1985;1:17-20.

17. O'Donnell K, Kistler HC, Cigelnik E, Ploetz RC. Multiple Evolutionary Origins of the Fungus Causing Panama Disease of Banana: Concordant Evidence from Nuclear and Mitochondrial Gene Genealogies. Appl. Biol. Sci. 1998;5:2044-9.

18. O'Donnell K, Cigelnik E. Two Divergent Intragenomic RDNA ITS2 Types within a Monophyletic Lineage of the Fungus Fusarium Are Nonorthologous. Mol. Phylogenet. Evol. 1997;7:103-16.

19. Untergasser A, Nijveen H, Rao X, Bisseling T, Geurts R, Leunissen JAM. Primer3Plus, an Enhanced Web Interface to Primer3. Nucleic Acids Res. 2007;35:71-4.

20. Jacobs A, Van Wyk PS, Marasas WFO, Wingfield BD, Wingfield MJ, Coutinho TA. Fusarium Ananatum Sp. Nov. in the Gibberella Fujikuroi Species Complex from Pineapples with Fruit Rot in South Africa. Fungal Biol. 2010;114:515-27.

21. Souza JT De, Trocoli RO, Monteiro FP. Plants from the Caatinga Biome Harbor Endophytic Trichoderma Species Active in the Biocontrol of Pineapple Fusariosis. Biol. Control. 2016;94:25-32.

22. Aquije GMDFV, Korres AMN, Buss DS, Ventura JA, Fernandes PMB, Fernandes AAR. Effects of Leaf Scales of Different Pineapple Cultivars on the Epiphytic Stage of Fusarium Guttiforme. Crop Prot. 2011;30:375-8.

23. Dita MA, Waalwijk C, Buddenhagen IW, Souza JT, Kema GHJ. A Molecular Diagnostic for Tropical Race 4 of the Banana Fusarium Wilt Pathogen. Plant Pathol. 2010.

24. Karlsson I, Edel-Hermann V, Gautheron N, Durling MB, Kolseth A-K, Steinberg C, Persson P, Friberg H. Genus-Specific Primers for Study of Fusarium Communities in Field Samples. Appl. Environ. Microbiol. 2016;82:491-501.

25. Seifert KA, Lévesque CA. Phylogeny and Molecular Diagnosis of Mycotoxigenic Fungi. Eur. J. Plant Pathol. 2004;110:449-71.

26. Nicolaisen M, Suproniene S, Nielsen LK, Lazzaro I, Spliid N.H, Justesen AF. Real-Time PCR for Quantification of Eleven Individual Fusarium Species in Cereals. J. Microbiol. Methods. 2009;7:234-40.

27. Gachon C, Mingam A, Charrier B. Real-Time PCR: What Relevance to Plant Studies? J. Exp. Bot. 2004;55:1445-54.

28. Kokkinos CD, Clark CA. Real-Time PCR Assays for Detection and Quantification of Sweetpotato Viruses. Plant Dis. 2006;90:783-8.

29. Paiva-Cavalcanti M, Regis-da-Silva CG, Gomes Y. Comparison of Real-Time PCR and Conventional PCR for Detection of Leishmania ( Leishmania ) Infantum Infection: A Mini-Review. J. Venom. Anim. Toxins Incl. Trop. Dis. 2010;16:537-42.

30. Lugert R, Schettler C, Gross U. Comparison of Different Protocols for DNA Preparation and PCR for the Detection of Fungal Pathogens in Vitro. Mycoses. 2006;49:298-304. 
31. McCartney HA, Foster SJ, Fraaije BA, Ward E. Molecular Diagnostics for Fungal Plant Pathogens. Pest Manag. Sci. 2003;59:129-42.

32. Lievens B, Thomma BPHJ. Recent Developments in Pathogen Detection Arrays: Implications for Fungal Plant Pathogens and Use in Practice. Phytopathology. 2005;95:1374-80.

33. Helena M, Fungaro P, Sartori D. An Overview on Molecular Markers for Detection of Ochratoxigenic Fungi in Coffee Beans. Brazilian Arch Biol Technol. 2009;52:1-9.

34. Ioos R, Fabre B, Saurat C, Fourrier C, Frey P, Marçais B. Development, Comparison, and Validation of Real-Time and Conventional PCR Tools for the Detection of the Fungal Pathogens Causing Brown Spot and Red Band Needle Blights of Pine. Phytopathology. 2009;100:105-14.

35. Lievens B, Brouwer M, Vanachter ACRC, Cammue BPA, Thomma BPHJ. Real-Time PCR for Detection and Quantification of Fungal and Oomycete Tomato Pathogens in Plant and Soil Samples. Plant Sci. 2006;171:155-65.

(C) (7) (5) 2018 by the authors. Submitted for possible open access publication BY NC BY NC) license (http://creativecommons.org/licenses/by-nc/4.0/). 